\title{
NCSTN wt Allele
}

National Cancer Institute

\section{Source}

National Cancer Institute. NCSTN wt Allele. NCI Thesaurus. Code C162433.

Human NCST N wild-type allele is located in the vicinity of $1 \mathrm{q} 23.2$ and is approximately 16 $\mathrm{kb}$ in length. This allele, which encodes nicastrin protein, plays a role in intramembrane cleavage of Notch and APP family proteins. Mutation of the gene is associated with familial acne inversa type 1. Mutagenesis of the gene can caused increased levels of amyloid-beta secretion and deletions in the gene may inhibit amyloid-beta production. 